Egypt. Acad. J. biolog. Sci., 2 (2): 69- 89(2009)

Email: egyptianacademic@yahoo.com

Received: 2/7/2009

A. Entomology

ISSN: 1687-8809

www.eajbs.eg.net

\title{
Ecological and taxonomic studies on the scale insects that infest mango trees at Qaliobiya governorate
}

\author{
Reda F. A. Bakr ${ }^{1}$ Rawda M. Badawy ${ }^{1}$; Saber F. Mousa² ${ }^{2}$ Laila S.Hamooda'; \\ Sahar A. Atteia \\ 1- Entomology Department, Faculty of Science, Ain Shams University, Cairo, Egypt. \\ 2- Plant protection Research Institute, Ministry of Agriculture, Dokki, Egypt
}

\begin{abstract}
This study aimed to determine the recent status of the scale insects that infest the mango trees at Qaliobiya governorate during visiting four mango orchards (El-Khanka, Shebeen El-Qanater, Benha \&El-Qanater El-Khayria, through twice visits monthly to each district for two successive years. This study was carried out to present an identification guide with key, diagnosis, important synonymes, figures \& illustrations to the fourteen collected mango scale pests which included in the four families, Coccidae, Pseudococcidae, Margarodidae and Diaspididae; in additions to give an attention to the most serious species, with notes on the agricultural precautions which could decrease the infestation. Mango leaf morphology and anatomy is used to explain the reasons for the mango variety recommendation.
\end{abstract}

Key words: Ecology, taxonomy, scale insects, mango trees

\section{INTRODUCTION}

Due to the great damage can be done by the scale insects not only by sucking the plant sap that give low photosynthesis and respiration which leads to curling, yellowing, dropping to leaves, so malformations, dwarfing \& decreasing fruit production (quality and quantity), even plant death, where the mealy bugs only can cause losses of 750 million American dollars per year (Moffit, 1999); but also due to the excretion of large amount of honey dew that rich in sugars and nitrogenous components, so give good media to sooty molt fungi that increase the inhibition of photosynthesis qualities of the plant (Radwaan, 2003). In addition to the insect secretion of the toxic saliva that resulted in malformed leaf and shoot growth, these characteristic symptoms similar to damages caused by viruses (Fisheries \& Foresty, 2008); on the other hand of bringing the associated insects: bees, ants and wasps that give the protection to these scales from their enemies, in turn of taking the honey dew. These specially ants (Fondling) (Myremcophiles, Sharaf, 2005) usually found in the vicinity of the scales and are cemented together to form a covering over the scale (Hamon\& Williams, 1984). So the ant associated with soft scale colonies are larger than the same scales on the same host without associated ants.

Most soft scales can reproduce sexually or parthenogenetically so many differences can be found in scale colonies, sexual dimorphism is apparent, male usually smaller, slender, lighter and winged, with vestigial mouthparts. In dense population the infestation appears not only on the lower surfaces, but also attack the upper surfaces, twigs, stems fruits \& even roots, it is very difficult to remove them from the fruits 
(Hosney, 1939). It is clear that, due to the differentiation in the climatic, agricultural \& the biotic factors the picture of mango pests reflect differences from the previous studies, so this work is used to establish the updated survey to mango soft, hard scales \& mealy bugs.

\section{MATERIALS AND METHODS}

Four orchards of mango trees (El-Khanka, Shebeen El-Qanater, Banha \& El-Qanater El khayria) in Qaliobiya governorate, were chosen for collecting soft, hard scale insects and mealybugs. The first district was cultivated by Hendi, the second with Langra \& Banha was cultivated with Alphonso; but El-Qanater El-Khayria was cultivated by Alphonso and Hendi, two ribbons in the same farm.

The collection was carried out twice monthly for two successive years from August 2005 to July 2007 in each area.

10 infested mango leaves were collected randomly from mango orchards, then these leaves were packed in paper bags with minute holes. The paper bages with infested leaves were taken to the laboratory for investigation.The collected mango leaves were picked up from the four main directions (East, West, South \&North), also at 4.5-5.5 meter of the tree height.

The qualitative and quantitative examination was done by using binocular microscope; microscopic slides were prepared for detail characters. Identification were done by using different keys as Ezzat (1965), Ezzat \& Husein (1967), Hamon \& Williams (1984) \& Miller etal, 2006. The leaf examination was done in Plant Department, Faculty of science, Ain Shams University.

The main climatic factors (Maximum Temperature (Max.Temp.), Minimum Temperature (Min.Temp.), Relative Humidity (R.H.), rain fall \& wind speed) were recorded at Qaliobiya governorate with the aid of Meteorological Agency.

For the quantitative facility, $1 \mathrm{x}=1-20 ; 2 \mathrm{x}=21-50,3 \mathrm{x}=51-100 ; 4 \mathrm{x}=101-300$; $5 \mathrm{x}=301-500 ; 6 \mathrm{x}=501-1000 ; 7 \mathrm{x}=$ above 1000 .

\section{RESULTS}

\section{Survey of scale insects on mango trees at Qaliobiya governorate}

The survey was carried out on mango trees in four districts (El-Khanka, Shebeen EL-Qanater, Benha \& EL- Qanater EL-khayria) at Qaliobiya governorate from August 2005 to July 2007 twice visits monthly.

The obtained data were listed in Tables I- IV and illustrated in figures 1- 4. The collected species and their comparative relative abundance from the four studied areas were given in table $\mathrm{V}$ and figures $5 \& 6$, the climatic factors are recorded in table VI.

1-El-Khanka mango orchard which was cultivated with Hendi variety, it was the richest orchard by scale insects of 3107 individuals as shown in table I and figure 1; where fourteen insect species were collected, the most abundant species was Pulvinaria psidii (Maskell) (35.6\%) of total collected species, then Aulacaspis tubercularis (Newsteed) (27.4\%), Lepidosaphes pallidula (Williams) (14.6\%), Parlatoria oleae (Clovee) (12.1\%) and Kilifia acuminata (Signoret) (6.5\%).The least abundant species were Aspidiotus nerii Bouche (2.2\%), Lindingaspis floridana (Ferris) (1\%), Icerya 
seychellarum (Westwood) (0.2\%) and Saissetia oleae ( Olive), Maconellicocus hirsutus (Green) (0.13\%), lastly Saissetia coffeae (Walker) (0.1 \%), Ceroplastes floridensis Comstock (0.1\%), then Aonidiella aurantii (Maskell) and Coccus hesperidum (L.) (0.03).

Table I: The collected scale insects that infest mango trees at El -Khanka orchard from August 2005-July 2007.

\begin{tabular}{|c|l|c|c|c|c|}
\hline \multirow{2}{*}{ Series } & \multicolumn{1}{|c|}{ Insect scientific name } & \multirow{2}{*}{ Family } & \multicolumn{2}{|c|}{$\begin{array}{c}\text { El-khanka } \\
\text { (Hendi) }\end{array}$} & \multirow{2}{*}{$\mathbf{x}$} \\
& & & No. & $\%$ & \\
\hline $\mathbf{1}$ & Lepidosaphes pallidula (Williams) & Diaspididae & 455 & 14.64 & $\mathbf{5 x}$ \\
\hline $\mathbf{2}$ & Aspidiotus nerii Bouche & Diaspididae & 69 & 2.22 & $\mathbf{3 x}$ \\
\hline $\mathbf{3}$ & Aulacaspis tubercularis (Newsteed) & Diaspididae & 850 & 27.36 & $\mathbf{6 x}$ \\
\hline $\mathbf{4}$ & Lindingaspis floridana (Ferris) & Diaspididae & 31 & 1.00 & $\mathbf{2 x}$ \\
\hline $\mathbf{5}$ & Parlatoria oleae (Colvee) & Diaspididae & 376 & 12.10 & $\mathbf{5 x}$ \\
\hline $\mathbf{6}$ & Aonidiella aurantii (Maskell) & Diaspididae & 1 & 0.03 & $\mathbf{1 x}$ \\
\hline $\mathbf{7}$ & Pulvinaria psidii (Maskell) & Coccidae & 1106 & 35.60 & $\mathbf{7 x}$ \\
\hline $\mathbf{8}$ & Saissetia oleae Oliver & Coccidae & 4 & 0.13 & $\mathbf{1 x}$ \\
\hline $\mathbf{9}$ & Saissetia coffeae (Walker) & Coccidae & 3 & 0.10 & $\mathbf{1 x}$ \\
\hline $\mathbf{1 0}$ & Kilifia acuminata (Signoret) & Coccidae & 200 & 6.44 & $\mathbf{4 x}$ \\
\hline $\mathbf{1 1}$ & Ceroplastes floridensis Comstock & Coccidae & 2 & 0.06 & $\mathbf{1 x}$ \\
\hline $\mathbf{1 2}$ & Coccus hespridum L. & Coccidae & 1 & 0.03 & $\mathbf{1 x}$ \\
\hline $\mathbf{1 3}$ & Icerya seychellarum (Westwood) & Margarodidae & 5 & 0.16 & $\mathbf{1 x}$ \\
\hline $\mathbf{1 4}$ & Maconellicoccus hirsutus (Green) & Psudococcidae & 4 & 0.13 & $\mathbf{1 x}$ \\
\hline & Total & & 3107 & $100 \%$ & \\
\hline
\end{tabular}

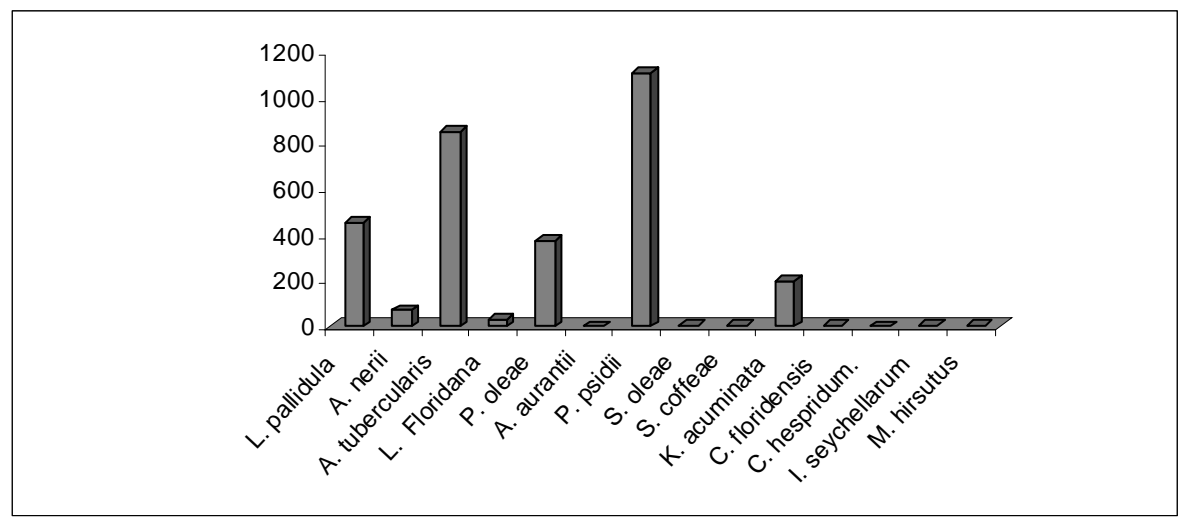

Fig. I: The collected scale insects on mango trees at El -Khanka orchard from August 2005 to July 2007.

2-Shebeen El Qanater mango orchard, which was cultivated with Langra variety, nearly gave a moderate picture of 1536 individuals as indicated in table II \& figure2. Although ten species were collected but the hard scales were the most abundant species than the soft scales, where Aulacaspis tubercularis (Newsteed) (32\%), Lepidosaphes pallidula (Williams) (25\%), Parlatoria oleae (Colvee) (19\%) were higher than the soft scales Kilifia acuminata (Signoret) (14\%) and Pulvinaria psidii (Maskell) (4\%).

3-Benha mango orchard, which was cultivated with Alphonso variety it was the poorly orchard of 202 individuals, where six species only were collected, the hard scales were the dominant collected species as Aspidiotus nerii Bouche (50\%), Lepidosaphes 
pallidula (Williams) (23\%), Parlatoria oleae (Colvee) (13\%) . But the only dense soft scale was Pulvinaria psidii (Maskell) (14\%) and the least represented species were Lindingaspis floridana (Ferris) and Icerya seychellarum (Westwood) (0.5\%) as clear in table III \& figure 3

4-EI Qanater mango orchard, which was cultivated with Hendi and Alphonse variety as two ribbons in the same farm, the resulted scales as in table IV \& figure 4, nearly ensured the same results, where $79.4 \%$ were collected from Hendi, in front of $20.6 \%$ from Alphonse; twelve species were collected totally 2299 individuals, the soft scales, Kilifia acuminata (Signoret) (34\%) was the most abundant species, then Aulacaspis tubercularis (Newsteed) (27.4\%) and Pulvinaria psidii (Maskell) (27\%), the least species were Coccus hespridum (L.), Ceroplastes floridensis Comstock and Saissetia coffeae (Walker) (0.04\%).

Table II: The collected scale insects on mango trees at Shebeen El-Qanater from August 2005-July 2007.

\begin{tabular}{|c|c|c|c|c|c|}
\hline \multirow[t]{2}{*}{ Series } & \multirow[t]{2}{*}{ Insect scientific name } & \multirow[t]{2}{*}{ Family } & \multicolumn{2}{|c|}{$\begin{array}{c}\text { Shebeen El- } \\
\text { Qanater }\end{array}$} & \multirow{2}{*}{$\begin{array}{c}\text { Langra } \\
\qquad \mathbf{x}\end{array}$} \\
\hline & & & No. & $\%$ & \\
\hline 1 & Lepidosaphes pallidula(Williams) & Diaspididae & 389 & 25.33 & $5 x$ \\
\hline 2 & Aspidiotus nerii Bouche & Diaspididae & 96 & 6.25 & $3 x$ \\
\hline 3 & Aulacaspis tubercularis(Newst.) & Diaspididae & 486 & 31.64 & $5 x$ \\
\hline 4 & Lindingaspis floridana (Ferris) & Diaspididae & 1 & 0.07 & $1 x$ \\
\hline 5 & Parlatoria oleae (Colvee) & Diaspididae & 286 & 18.62 & $4 x$ \\
\hline 6 & Aonidiella aurantii (Maskell) & Diaspididae & 0 & 0.00 & 0 \\
\hline 7 & Pulvinaria psidii (Maskell) & Coccidae & 62 & 4.04 & $3 x$ \\
\hline 8 & Saissetia oleae Oliver & Coccidae & 2 & 0.13 & $1 x$ \\
\hline 9 & Saissetia coffeae (Walker) & Coccidae & 0 & 0.00 & 0 \\
\hline 10 & Kilifia acuminata (Signoret) & Coccidae & 208 & 13.54 & $4 x$ \\
\hline 11 & Ceroplastes floridensis Comstock & Coccidae & 0 & 0.00 & 0 \\
\hline 12 & Coccus hespridum L. & Coccidae & 0 & 0.00 & 0 \\
\hline 13 & Icerya seychellarum (Westwood) & Margarodidae & 3 & 0.20 & $1 x$ \\
\hline \multirow[t]{2}{*}{14} & Maconellicoccus hirsutus (Green) & Psudococcidae & 3 & 0.20 & $1 x$ \\
\hline & Total & & 1536 & $100 \%$ & \\
\hline
\end{tabular}

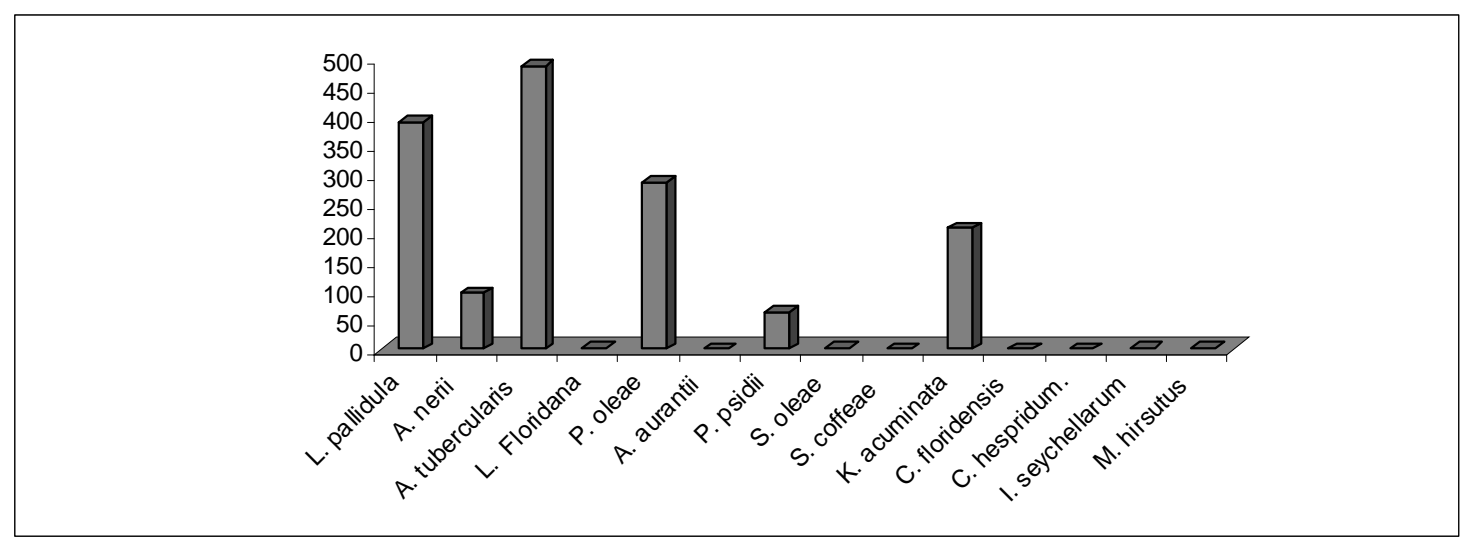

Fig. II: The collected scale insects on mango trees at Shebeen El-Qanater from August 2005-July 2007. 
Table III: The collected scale insects on mango trees at Benha from August 2005-July 2007.

\begin{tabular}{|c|l|l|c|c|c|}
\hline \multirow{2}{*}{ Series } & \multirow{2}{*}{ Insect scientific name } & \multirow{2}{*}{ Family } & \multicolumn{2}{|c|}{ Benha } & \multirow{2}{*}{ Alphonso } \\
\cline { 4 - 6 } & & & No. & $\%$ & $\mathbf{x}$ \\
\hline $\mathbf{1}$ & Lepidosaphes pallidula (Williams) & Diaspididae & 46 & 22.77 & $\mathbf{2 x}$ \\
\hline $\mathbf{2}$ & Aspidiotus nerii Bouche & Diaspididae & 100 & 49.50 & $\mathbf{3 x}$ \\
\hline $\mathbf{3}$ & Aulacaspis tubercularis (Newsteed) & Diaspididae & 0 & 0.00 & $\mathbf{0}$ \\
\hline $\mathbf{4}$ & Lindingaspis floridana (Ferris) & Diaspididae & 1 & 0.50 & $\mathbf{1 x}$ \\
\hline $\mathbf{5}$ & Parlatoria oleae (Colvee) & Diaspididae & 26 & 12.87 & $\mathbf{2 x}$ \\
\hline $\mathbf{6}$ & Aonidiella aurantii (Maskell) & Diaspididae & 0 & 0.00 & $\mathbf{0}$ \\
\hline $\mathbf{7}$ & Pulvinaria psidii (Maskell) & Coccidae & 28 & 13.86 & $\mathbf{2 x}$ \\
\hline $\mathbf{8}$ & Saissetia oleae Oliver & Coccidae & 0 & 0.00 & $\mathbf{0}$ \\
\hline $\mathbf{9}$ & Saissetia coffeae (Walker) & Coccidae & 0 & 0.00 & $\mathbf{0}$ \\
\hline $\mathbf{1 0}$ & Kilifia acuminata (Signoret) & Coccidae & 0 & 0.00 & $\mathbf{0}$ \\
\hline $\mathbf{1 1}$ & Ceroplastes floridensis Comstock & Coccidae & 0 & 0.00 & $\mathbf{0}$ \\
\hline $\mathbf{1 2}$ & Coccus hespridum L. & Coccidae & 0 & 0.00 & $\mathbf{0}$ \\
\hline $\mathbf{1 3}$ & Icerya seychellarum (Westwood) & Margarodidae & 1 & 0.50 & $\mathbf{1 x}$ \\
\hline $\mathbf{1 4}$ & Maconellicoccus hirsutus (Green) & Psudococcidae & 0 & 0.00 & $\mathbf{0}$ \\
\hline & & & $\mathbf{2 0 2}$ & & \\
\hline
\end{tabular}

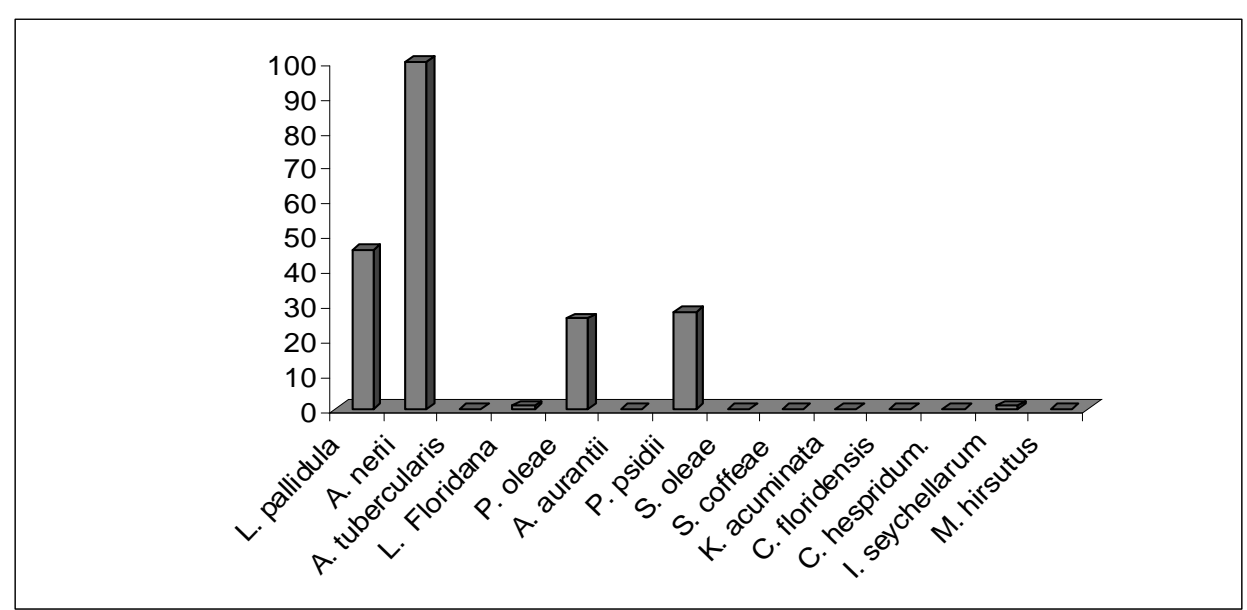

Fig. III: The collected scale insects on mango trees at Benha from August 2005-July 2007.

The comparative abundance of the scale insects on mango trees at Qaliobiya governorate (El-Khanka, Shebeen El-Qanater, Benha \& El-Qanater El khayria ) from August 2005 to July 2007 was shown in table IV and figure 4 \& 5; it is clear that: the most serious scale insect pests were: the hard scale Aulacaspis tubercularis (Newsteed) $27.5 \%$ of the all collected species and represented from three localities, but the soft scale Pulvinaria psidii (Maskell ) 25\% of the all collected species, it was the most abundant species, where it was collected from the four localities. Then the soft scale Kilifia acuminate (Signoret ) (17\%), after this the hard scales Lepidosaphes pallidula (Williams) (14\%), Parlatoria oleae(Clovee) (11\%), Aspidiotus nerii Bouche (4\%), Lindingaspis floridana (Ferris) (0.7\%)and then Aonidiella aurantii (Maskell) (0.4\%), Icerya seychellarum (Westwood)(0.3\%), Saissetia oleae Oliver \& Maconellicoccus hirsutus (Green) (0.2\%), the low dense species are Saissetia coffeae (Walker)\& 
Ceroplastes floridensis Comstock (0.1\%) and lastly Coccus hespridum L. (0.03\%). But El-Khanka was the densest district, Benha was the poorest district.

Table IV: The collected scale insects on mango trees at El -Qanater orchard from August 2005-July 2007.

\begin{tabular}{|c|c|c|c|c|c|c|c|}
\hline \multirow{2}{*}{ Series } & \multirow{2}{*}{ Insect scientific name } & \multirow{2}{*}{ Family } & \multicolumn{2}{|c|}{ El-Qanater } & \multirow{2}{*}{ No. } & \multirow{2}{*}{$\%$} & \multirow{2}{*}{$\mathbf{x}$} \\
\hline & & & Hendi & Alphonso & & & \\
\hline 1 & Lepidosaphes pallidula(Williams) & Diaspididae & 80 & 18 & 98 & 4.26 & $3 x$ \\
\hline 2 & Aspidiotus nerii Bouche & Diaspididae & 11 & 5 & 16 & 0.70 & $1 x$ \\
\hline 3 & Aulacaspis tubercularis (Newsteed) & Diaspididae & 492 & 138 & 630 & 27.40 & $6 x$ \\
\hline 4 & Lindingaspis floridana (Ferris) & Diaspididae & 12 & 7 & 19 & 0.83 & $1 x$ \\
\hline 5 & Parlatoria oleae (Colvee) & Diaspididae & 93 & 24 & 117 & 5.09 & $4 x$ \\
\hline 6 & Aonidiella aurantii (Maskell) & Diaspididae & 0 & 0 & 0 & 0.00 & $\mathbf{0}$ \\
\hline 7 & Pulvinaria psidii (Maskell) & Coccidae & 501 & 120 & 621 & 27.01 & $6 x$ \\
\hline 8 & Saissetia oleae Oliver & Coccidae & 7 & 0 & 7 & 0.30 & $\mathbf{1 x}$ \\
\hline 9 & Saissetia coffeae (Walker) & Coccidae & 1 & 0 & 1 & 0.04 & $1 x$ \\
\hline 10 & Kilifia acuminata (Signoret) & Coccidae & 607 & 162 & 769 & 33.45 & $6 x$ \\
\hline 11 & Ceroplastes floridensis Comstock & Coccidae & 1 & 0 & 1 & 0.04 & $1 x$ \\
\hline 12 & Coccus hespridum L. & Coccidae & 1 & 0 & 1 & 0.04 & $\mathbf{1 x}$ \\
\hline 13 & Icerya seychellarum (Westwood) & Margarodidae & 14 & 0 & 14 & 0.61 & $\mathbf{1 x}$ \\
\hline \multirow[t]{3}{*}{14} & Maconellicoccus hirsutus (Green) & Psudococcidae & 5 & 0 & 5 & 0.22 & $1 x$ \\
\hline & Total & & 1825 & 474 & 2299 & & \\
\hline & $\%$ & & 79.38 & 20.62 & & & \\
\hline
\end{tabular}

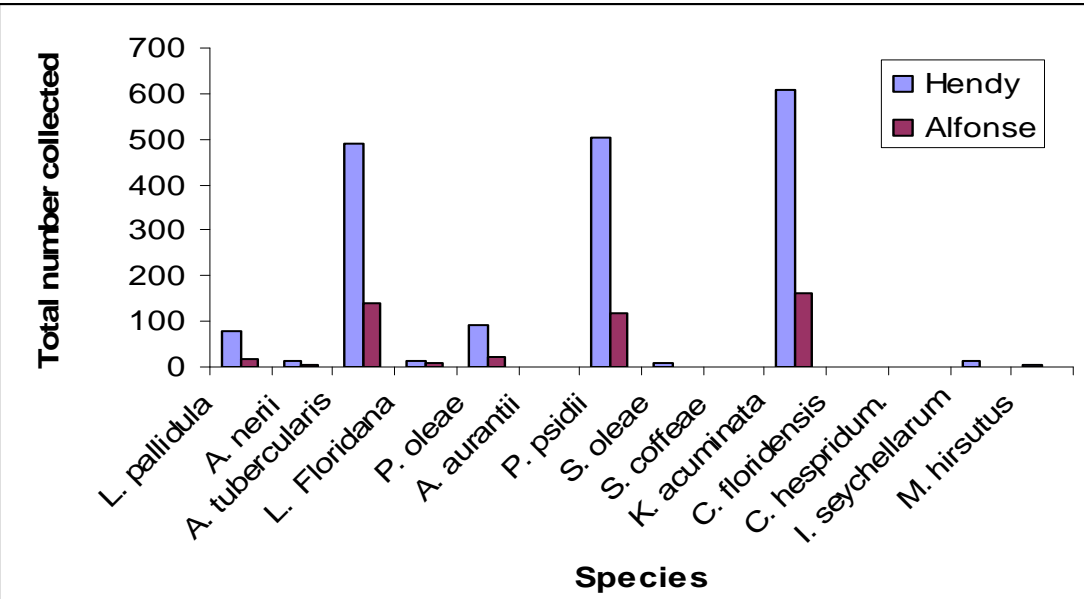

Fig. IV: The collected scale insects on mango trees at El-Qanater orchard from August 2005-July 2007.

From the monthly collection, it was noticed that: during the cooler weather, the infested leaves were concentrated at east direction in front of sunrise, while in summer weather, the infested leaves were dense far from sunrise usually west direction. It was also cleared that: Alphonso is a resistant variety specially to soft scales and mealy bugs, a partially resistance to the hard scales this resistance as shown in figure 51 and table VII may be related to thick epidermis, deeper vascular bundle(xylem \& phloem), excess schlerenchyma(red dead lignified cells), with accumulated lignin and pericyclic fibers; in 
addition to the fewer numbers of resin ducts(food source) when compared with the other more susceptible variety (Hendi) (Figure52).

Table V: Comparative relative abundance of the scale insects on mango trees at Qalyubia governorate from August 2005-July 2007

\begin{tabular}{|c|c|c|c|c|c|c|c|c|}
\hline Series & $\begin{array}{c}\text { Insect scientific } \\
\text { name }\end{array}$ & khanka & $\begin{array}{c}\text { El- } \\
\text { Qanater }\end{array}$ & $\begin{array}{c}\text { Shebeen } \\
\text { El- } \\
\text { Qanater }\end{array}$ & Benha & Total & $\%$ & $\mathbf{x}$ \\
\hline 1 & Lep.. pallidula & 455 & 98 & 389 & 46 & 988 & 13.8 & $6 x$ \\
\hline 2 & Asp. nerii & 69 & 16 & 96 & 100 & 281 & 3.94 & $4 x$ \\
\hline 3 & Aul. Tubercularis & 850 & 630 & 486 & 0 & 1966 & 27.5 & $7 \mathbf{x}$ \\
\hline 4 & Lind. floridana & 31 & 19 & 1 & 1 & 52 & 0.73 & $3 \mathbf{x}$ \\
\hline 5 & Par. oleae & 376 & 117 & 286 & 26 & 805 & 11.3 & $6 x$ \\
\hline 6 & Aonid.aurantii & 1 & 0 & 0 & 28 & 29 & 0.41 & $2 x$ \\
\hline 7 & Pulv. psidii & 1106 & 621 & 62 & 0 & 1789 & 25.1 & $7 \mathbf{x}$ \\
\hline 8 & Sais. oleae & 4 & 7 & 2 & 0 & 13 & 0.18 & $1 x$ \\
\hline 9 & Sais. coffea & 3 & 1 & 0 & 0 & 4 & 0.06 & $1 x$ \\
\hline 10 & Kilifia acuminata & 200 & 769 & 208 & 0 & 1177 & 16.5 & $7 x$ \\
\hline 11 & Cero. floridensis & 2 & 1 & 0 & 1 & 4 & 0.06 & $1 x$ \\
\hline 12 & Coccus hespridum L. & 1 & 1 & 0 & 0 & 2 & 0.03 & $1 x$ \\
\hline 13 & Icerya seychellarum & 5 & 14 & 3 & 0 & 22 & 0.31 & $2 x$ \\
\hline \multirow[t]{3}{*}{14} & Macon. hirsutus & 4 & 5 & 3 & 0 & 12 & 0.17 & $1 x$ \\
\hline & Total & 3107 & 2299 & 1533 & 202 & 7141 & & \\
\hline & $\%$ & 43.51 & 32.19 & 21.47 & 2.83 & 100 & & \\
\hline
\end{tabular}

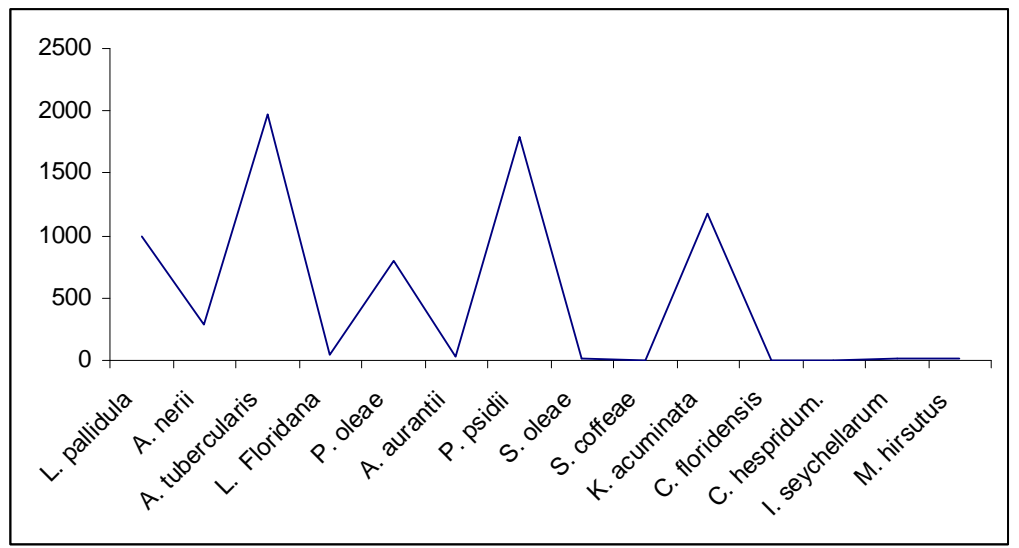

Fig. V: The comparative abundance of the scale insects on mango trees from the four studied areas during the period of investigation

So these anatomical investigations, with many others may be are considered as antiherbivore defense, as physically difficult and energetically costly for insect penetration. 
Table VI: Climatic factors during collection of scale insects on mango trees at Qalyubia governat through the perod of study.

\begin{tabular}{|l|c|c|c|c|c|}
\hline Months & Min. temp & Max. temp & R.H & Rain fall & Wind speed \\
\hline August & 25.40 & 36.79 & 58.93 & 0 & 10.50 \\
\hline September & 19.84 & 33.42 & 60.49 & 0 & 10.33 \\
\hline Octobar & 15.40 & 25.63 & 45.75 & 0 & 13.10 \\
\hline Novamber & 12.05 & 19.50 & 54.71 & 0 & 9.05 \\
\hline December & 10.84 & 16.23 & 59.99 & 2.00 & 9.95 \\
\hline January & 7.72 & 15.55 & 56.33 & 4.00 & 12.80 \\
\hline Feboury & 10.85 & 18.83 & 49.54 & 12.00 & 13.98 \\
\hline March & 12.65 & 23.33 & 54.25 & 6.00 & 10.06 \\
\hline April & 15.97 & 26.86 & 52.50 & 0 & 10.55 \\
\hline May & 18.26 & 27.14 & 49.47 & 0 & 13.07 \\
\hline Jun & 22.18 & 30.23 & 48.40 & 0 & 17.08 \\
\hline July & 23.68 & 33.95 & 66.14 & 0 & 10.55 \\
\hline
\end{tabular}

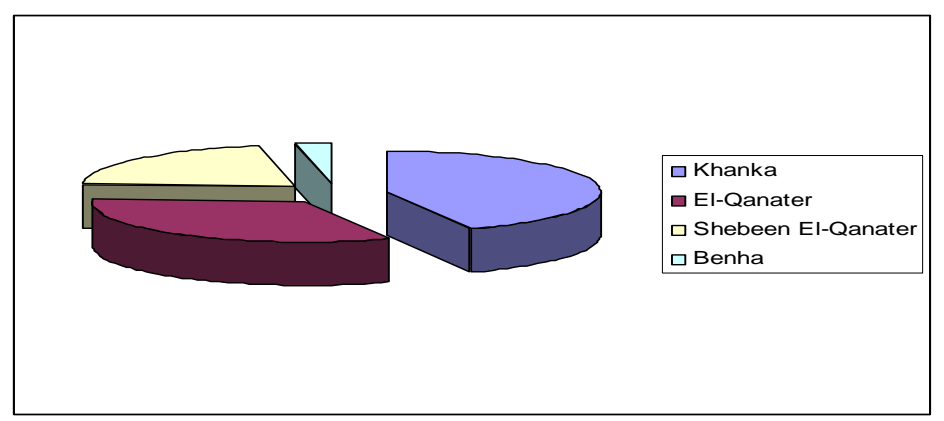

Fig. VI: The relative abundance of the all collected scale insects on mango trees from the four studied areas.

Table VII: Comparative leaf contents of Alphonso and Hendi variety

\begin{tabular}{|c|c|c|}
\hline characters & Alphonso & Hendi \\
\hline $\begin{array}{c}\text { schlerenchyma (red dead } \\
\text { lignified cells) }\end{array}$ & $\begin{array}{c}\text { more dense (in upper and lower } \\
\text { surface) }\end{array}$ & less dense \\
\hline resin ducts (food sources) & from 5 to 8 10 to 13 \\
\hline $\begin{array}{c}\text { accumulated lignin and } \\
\text { pericyclic fibers }\end{array}$ & deeply accumlated & fine \\
\hline $\begin{array}{c}\text { Depth of the vascular bundle } \\
\text { from the lower epidermis }\end{array}$ & 100 micro meter & thin meter \\
\hline Epidermis & thick & the \\
\hline
\end{tabular}

\section{Taxonomic studies}

During the present study, 14 scale insects were collected from mango trees. These species are belonging to four families: Coccidae (6spp.); Diaspididae (6spp.); Margarodidae (1sp.) and Pseudococcidae (1sp.). The adult female of the collected species can be diagnosed as follow: 


\section{Key to mango scale insects (females)}

1-Pink in color (eggs, immature \& adults), covered with short filamentous white waxy secretion, female oval, microscopically with 9-segmented antenna and numerous dorsal oral rim ducts, male with one pair of wing, vestigial mouth parts, long antenna and two long caudal filaments (fig.48)...............................Maconellicoccus hirsutus

(Family Pseudococcidae)

-Not pink color, without these filamentous white waxy secretion, male \& female not as the above....

2-Yellowish white, adult female enclosed in a tough spherical cyst composed of very thin layers, adult female looks like a hairy ball with purplish body contents (fig.42), microscopically, antenna short \& stout, eyes well developed...........Icerya seychellarum

(Family Margarodidae)

-Not enclosed in spherical cyst, female not like a hairy ball........................... 3-Hard scale covered with armored scale, microscopically without abdominal spiracles, the anus without a rigid anal ring and anal plates, legs not well developed, male head fused with prothorax...................................... 9 (Family Diaspididae). -Soft scale without armored scale, microscopically with abdominal spiracles, anus with anal rings and plates, legs usually well developed, male head with fairly distinct neck.

(Family Coccidae). 4-Triangular in shape, with blunt pointed front tip, yellowish green, mesothoracic and metathoracic coxae different in shape than prothoracic coxae (Figs 15, 16 \&17), ventral ducts absent. Kilifia acuminata -Oval or globular, meso and metathoracic coxae similar in shape to prothoracic coxae, ventral tubular ducts present.

5-Yellowish brown, with transparent area and brown spots (fig.40), dorsal setae spine like, cylindrical, capitate and clavate, with numerous preopercular pores (fig.23) and four apical setae at anal plate. Coccus hespridium -Other colors, without transparent area and brown spots............................6 6-Green in color, flat, with large discoidal pores (fig.7), extending from anterior of anal plates to head. .Pulvinaria psidii

-Other colors, without these discoidal pores 7

7-Whitich in color, with one dorsal plate and 6 lateral plates (fig.41), without H shaped ridges, microscopically with one pair of long setae between antennae -Brownish in color, without dorsal and lateral plates, with $\mathrm{H}$ shaped ridges, without these long setae. ...8

8- Dark brownish, with clear $\mathrm{H}$ shaped ridges (fig.27), legs without tibiotarsus

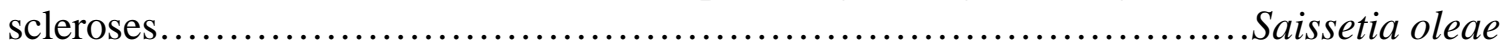
Yellowish brown, with slightly conspicuous $H$ shaped ridges (fig.43), legs with tibiotarsus scleroses................................................Saissetia coffeae 9- Triangular, elongated, brownish (fig.44), adult elongate, brownish, antennae each with large setae, single seta with bifurcate base, with two microducts near each antenna..................................................... -Oval or circular, other color, adult oval or circular, antennae without these setae or ducts. 
10-Large circular, whitish, flat, thin, with dark oval spot (fig.46), microscopically the body widest above the anterior spiracles, macroducts absent from thorax and head, female with elongate pygidium..................................Aulacaspis tubercularis -Not as the above. .11

11-Circular, flat, reddish, with darker spot (fig.45), microscopically the female with highly sclerotized prosoma, lateral lobes project posteriorly than the apex of pygidium........................................................ -Without reddish color, without highly sclerotized prosoma, lateral lobes not projecting..... .12

12-Grayish yellow with yellow spots (fig.47), usually naked, adult female pyriform, narrowed posteriorly with reddish pygidium and free abdominal segments.........................................................

-With dark spots, not naked, adult circular, not narrowed posteriorly ..................13 13- With very hard wax film, with circular lines, median raised darker area, adult brown (fig.49), microscopically mmembranous except the pygidium, apically rounded................................................. Lindengaspis floridana -Without very hard wax and circular lines, median spots not highly raised, adult violet in color, not rounded apically (fig.50). Parlatoria oleae

\section{Family Coccidae}

Pulvinaria psidii Maskell, 1893 (Green shield scale)(Figs. 7-12)

Pulvinaria psidii Maskell, 1893. Tras. Proc. New Zeland Inst. 11 : 223.

Chloropulvinaria psidii (Maskell), Borchsenius, 1957. Akad. Nauk. Zool Inst 9: 217.

Diagnosis: Adult female scale is oval, green, 3mm long, $2.5 \mathrm{~mm}$ wide. Microscobically body setae short, straight, spine-like with sharp apices, discoidal pores in a longitudinal group anterior to anal plates (Fig.7), anal plates triangular with nearly equal sides, each plate with four apical setae (Fig.8); bitubular pores (Fig.9) scattered over surface. Antenna 8-segmented; spiracles usually enclosed by a sclerotized plate (Fig.10); the dorsal tubular ducts (Fig.11) are numerous, marginal setae expanded and fringed (Fig.12), multilocular pores with 10 loculi above abdominal segmentation.

\section{Kilifia acuminata (Signoret, 1873) (Acuminate scale)(Figures 13-21)}

Lecanium_acuminata Signoret, 1873, Ann Entomol. Soc. France, 2:397.

Diagnosis: Adult female scale is triangular in shape, with blunt pointed front tip, yellowish green in color, thin and flat, $2.5-3 \mathrm{~mm}$ long, $1.5-2 \mathrm{~mm}$ wide. Microscopically the dorsal setae clavate, with 10 submarginal tubercles (Fig. 13), small group of discal pores (Fig.14) anterior to anal plates which locates near the center. Legs ventrally well developed, meso and metacoxa with characteristic shape (Figs.15, 16, 17), with thin tibia and very short tarsi. Spiracular quinquelocular pores (Fig.18) smaller, angular than that anal quinquelocular pores (Fig.19). Antenna with 8 segments, marginal setae bifurcate (Fig.20), spiracular setae with median long curved one and two sharp laterals (Fig21).

\section{Coccus hesperidum Linnaeus, 1758 (Brown soft scale)}

Coccus hesperidum L., 1758: Hamon \& Williams, 1984, Florida department of agriculture \& consumer: 41. (Figures. 22-26:40)

Diagnosis: Adult female scale is yellowish-brown, with transparent area and brown spots; oval, slightly convex in dense population, 2-3mm long, 1.5-2 mm wide, with spineshaped dorsal setae, 8 submarginal tubercles (Fig.22), with numerous preopercular pores (Fig.23), the anal plate with four apical setae. Antenna with seven segments (Fig.24); 
Legs well developed with tibiotarsal scleroses; tubular ducts (Fig.25) concentrated at mesocoxal area, multilocular pores with10 loculi (Fig.26), presented around the anal plates.

Saissetia oleae (Olivier, 1791) (Black scale) (Figures 27-32)

Coccus oleae Olivier,1791,Encycl. Method.,Hist. Nat. Insectes 6: 95.

Diagnosis: Adult female scale is dark brownish, rounded, convex, with $\mathrm{H}$ shaped ridges (Fig.27), 2.5-3.5mm long, 1.5-2.5 mm wide. Microscoically with oval cell-like clear areas, numerous spine-like dorsal setae, 10 submarginal tubercles (Fig.28), numerous discoidal pores (Fig.29) near anal plate, the anal plate (Fig.30) with large seta. Legs without tibiotarsal scleroses, multilocular pores (Fig.31) concentrated above the anal plate, with 12 loculi, quelocular pores (Fig.32) concentrated beside the spiracles, tubular ducts with thin filament

Saissetia coffeae (Walker, 1852) (Hemispherical scale) (Figures 33-35,43) Lecanium coffeae Walker, 1852 London Newman: 1079.

Diagnosis: Adult female scale is brownish, the $\mathrm{H}$ ridges slightly conspicuous, oval, with oval clear area, 2-3.5 mm long, 2-3mm wide. Microscopically with dorsal small stout setae, more than 10 discoidal pores concentrated anterior to anal plate; antennae with eight segments; legs with tibiotarsus scleroses; ventral tubular duct with wide filament (Fig.33) and few thin filaments (Fig.34) ; spiracular setae(Fig.35) with much larger median one and two small laterales.

Ceroplastes floridensis Comstock, 1881 (Florida wax scale) (Figures 36-39, 41)

Ceroplastes floridensis Comstock,1881. Dept. Agric. Comnr. Agric. Rpt.: 331.

Diagnosis: Adult female scale is whitish, oval dorsally, without a horn or plates and nuclei, 2-3.5 mm long, 1.5-3 mm wide. Microscopically with trilocular (Fig.36) and bilocular pores (Fig.37) except in the marginal area; anal process short, conical and sclerotized; antenna 6-segmented; legs well developed; with numerous quinquelocular pores (Fig.38) beside the spiracles; the tubular ducts with expanded basal filaments (Fig.39).

Family Pseudococcidae

Maconellicoccus hirsutus (Green, 1908) (Pink hibiscus mealy bug) (Fig.48)

Phenacoccus hirsutus Green, 1908. Coccidae of Ceylon.IV, Dulau, London: 171-249. Maconellicoccus hirsutus (Green), Ezzat,Y.M.,1958.Bull.Entom. Egypt XLii: 377.

Diagnosis: Eggs, immature and adults are pink in color, with pink body fluids, but covered with short filamentous white waxy secretion; adult female 2.5-4 mm long, oval, flattened. Microscopically with 9- segmented antenna, numerous dorsal oral rim ducts and long flagellated dorsal setae, Legs normal in size, dorsal body setae stout at basal half and flagellated at apex, with few shorter setae between the others, ventral setae longer, less stout and more flagellated. Adult male as shown in figure 41(after Wales, 2009) has one pair of very simple wings, long antennae and no mouth parts.

\section{Family Margarodidae}

Icerya seychellarum (Westwood, 1855) (Seychelles scale) (Fig.42)

Icerya seychellarum Westwood, 1855. Pro. Entomol.Soc. London, 1871, iii.

Diagnosis: It is characterized by the absence of the long, slender glassy filaments dorsally Figures 42 a (after Fisheries \& Forsesty, 2008), b; microscopically with open center pores in the marginal clusters and transverse rows; abdominal spiracles in three pairs; multipores with a large circular or subcircular center, without loculi; pores with a 
bilocular, trilocular, quadrilocular, reniform or star-shaped center and with 0-12 outer loculi.

Family Diaspididae

Lepidosaphes pallidula (Williams, 1969) (Maskel or Oystershell scale) (Fig. 44)

Mytilaspis pallida Green, 1896.Indian Museum Notes 4:5

Insulaspis pallidula Williams 1969b.Entomol. Month. Mag., 105:114.

Insulaspis pallida Borchsenius,1963.Zoologichekii Zhurnal,42:1173.

Insulaspis pallidulaWilliams,1969.Entomologists Monthly Magazine,105:114.

Diagnosis: Adult female straight, yellow or brownish; male lighter \& smaller; usually found in aggregation groups or clusters, become darker with age. Microscopically elongate, membranous except the pygidium; head margin rounded anteriorly, without lateral tubercles and minute spinules. Pygidium with two pairs of lobes, third and fourth pairs represented by a series of small points. Gland spines with single microduct, additional smaller gland spines present from the third to fifth segment, each with five gland spines, metathorax with six tubular like gland spines near each spiracle. Eyes difficult to see; antenna with large setae, single seta with bifurcate base, with two microducts near each antenna.

Aonidiella aurantii (Maskell, 1879) (California red scale) (Fig. 45)

Aspidiotus aurantii Maskell, 1879. Trans. Proc. New Zealand Inst. 11: 187 - 228.

Diagnosis: The female scale is circular, $1.5-2 \mathrm{~mm}$, flat, reddish with darker central exuvae; male scale shorter, grayish-brown with submarginal darker exuvae. Microscoically, female with highly sclerotized prosoma, lateral lobes project posteriorly than the apex of the pygidium; abdominal segments without prepygidial macroducts; pygidium with apophyses and scleroses.

Aulacaspis tubercularis (Newstead, 1906) (Mango scale) (Fig.46)

Diaspis tubercularis Newstead, 1906. Quart. J. Inst. Comm. Res. 1: 73.

Diagnosis: Female scale is circular, whitish, flat, thin and transparent, with dark oval spot (excuviae). Male scale is smaller, rectangular, and white with three raised longitudinal ridges. Microscopically, the body widest above the anterior spiracles, the posterior spiracles usually associated with spiracular pores and macroducts absent from thorax and head; pygidium with well developed median lobes, with submarginal black spot, male, elongate, white, without this exuvia, black spot, The adult female is characteristically shaped with , elongate and somewhat parallel-sided pygidium.

Aspidiotus nerii Bouche, 1833(Oleander scale) (Fig.47)

Aspidiotus nerii Bouche, 1833. Nat. Schad. Nutz. Garten - Insek: 30-33.

Diagnosis: The scale is flattish, circular, grayish yellow with central yellow pellicles which are usually naked, adult female pyriform, lighter in color, narrowed posteriorly, 1$2 \mathrm{~mm}$ in diameter, reddish pygidium, with free abdominal segments. Pygidium with four groups of circumgenital glands and three pairs of lobes; plates very long and deeply fringed.

\section{Lindingaspis floridana Ferris, 1942 (Florida scale) (Fig.49)}

Lindengaspis floridana Ferris, 1942. Atlas of Scale insects North America,4.

Diagnosis: Female scale is circular, brownish, with circular lines; median raised darker area (exuvia); 2-2.5 mm, with very hard wax film; the adult female is brown, male lighter, smaller. Microscoically membranous except the pygidium, which is large, long, 
epically rounded, with three pairs of pygidial lobes, plates very small and fringed, paraphysis small and slender. Dorsal ducts few and very slender.

Parlatoria oleae (Clovee, 1880) (Olive scale) (Fig.50)

Diaspis oleae Clovee, 1880. Gacet. Agri. Minist. Fomento, 14: 21-41.

Diagnosis: Female scale 1.0-2.0 mm, circular or oval, grayish yellow, with darker subterminal exuviae. Male scale lighter and smaller, with terminal exuviae; eggs, immature stages, adult female are violet in color, adult male winged. Microscopically adult female with two bar ducts; 10 ducts tubercles in four submarginal cephalothoracic groups on each side; pygidium with three pairs of rounded unilibulate lobes; with two submedian macroducts on either side of the perivulvular pores.

\section{DISCUSSION}

Fourteen insect species of mango scales were collected from El-Qaliobiya governorate during this study, this number is equal to that of the previous survey from eight governorates by Kwaiz 1999, but the picture shows many differences: instead of the last serious pest, fig wax scale, Ceroplastes rusci, then the recent mango scale Ceroplastes floridensis has been collected, this may be due to the absence of fig trees in the vicinity of the mango trees, where the mango is a secondary host for fig wax scale, this can also explain the absence of the ice citrus scale Unaspis citri during this collection. Many other changes specially in family Coccidae as Pulvinaria psidii which become the most serious soft scale and not collected with Kwaiz 1999, also Saissetia oleae and Saissetia coffea, this ensured the easily spreading the scale insects specially during cultivated activities and many scales are polyphagous (Waston, 2009).

Many other changes especially in family Diaspididae are made according to the recent nomenclature, synonyms are cleared. Due to the wide range of the morphological differences specially in the polyphagous and parthenogenatic strains, so the identification of most scale insects must be accompanied with diagnosis, figures or illustrations to decrease many confusions (Hamon \& Williams, 1984). The scale insects appear to be very sensitive to the biotic and abiotic factors specially to the microclimatic factors as irrigation methods, distances between the trees through the process of pruning the trees, many other factors can effectely decrease infestation.

Mango variety is a very important factor that affect the mango scale list, where the Alphonso resistant variety shows morphological and anatomical adaptations as the thicker epidermis\& schlerenchyma, deeper vascular bundle, condense pericyclic fibers and lignin, in addition to fewer numbers of resin ducts(food sources) that act as physically difficult and energetically cost for insect penetration; these results agree with the chemical analysis of mango leaves made by Radwan 2003, where the total carbohydrates are higher in Hendi susceptible variety than Alphonso resistant variety; in contrast, the repellant or toxic secondary metabolites are higher in Alphonso.

Many other explanations can be cleared through especial analysis, for example, the types and amounts of amino acids as mentioned by Laila, 2002: the larger amount of glutamine can cause paralysis and reduction of heart beats, so the concentrations and functions of some amino acids require future studies to give obvious determination.

Finally, according to these coordinated results, we can repeated that the highly susceptible variety to soft, hard scale insects and mealy bugs, is not recommended now 
for new cultivation till the genes for resistance in Alphonso is incorporated to other varieties by genetic engineering scientists to decrease the infestation by $79.4 \%$ and improve the mango product.

\section{REFRENCES}

Abed El-Mohimen, B. (2003). Ecological studies on the red-striped sugarcane soft scale, Pulvinaria tenuivalvata (Newstead) (Homoptera:coccidae) in upper Egypt. Archives-of- Phytopathology -and - plant-protection. 2003; 36 (3/4): 161 - 172.

Alek sidze, G; Ascher, K. R. and Ben, D.y. (1995). Armored scale insect (Diaspididae), pests of fruit orchards and their control in the republic of Georgia., Israel $\mathrm{J}$ Enomol. 29: 187 - 190.

Beshir, M. and Hosney, M. (1939). Some mealy bugs of Egypt and experiments on their control by means of chemicals.Tech. and Sci.Service Bulletin, 209:1-16.

Copland, M. J. W. (1984). Scale insects on fruit trees leaflet- Ministry-of- Agriculture,Fisheries- and - food,- uk. (88): 8pp .

Elwan, E.A.H. (2005). Population dynamics of Maskell scale, insulaspis pallidula (Green) (Homoptera-Diaspididae), on mango trees in Egypt. Egyptian- Journalof- Agriculttural-Research. 2005; 83 (3): 1199 - 1212.

Ezzat,Y. M. (1958). Maconellicoccus hirsutus (Green), A new genus, with redescription of the species. Bull. Soc.Entomol. Egypt XLII: 377.

Ezzat, Y. M. (1958). Classification of the scale insects, family Diaspididae. Bull. Soc.Entomol. Egypt XLII: 235-251.

Ezzat, Y. M. and Hussein, N. A. (1967). Redescription and classification of the family Coccidae in U.A.R. (Homoptera: Coccidae).Bull.Soc. ent.Egypte, LI: 359- 425.

Fisheries and Foresty (2008). Austrralian insect common names. . Australian vernment.Department of Agriculture. http://www.ento.csiro.au/aicn/index.htm

Gupta, B.p. and Singh, y.p. (1988). Mango scale insect occurrence in western Uttar Pradesh and their control. Progressive - Horticulture. 20 (3-4): 357 - 361.

Hamon, A.B and Williams, M.L.(1984). Arthropods of Florida \&Neighboring land areas. The soft scale insects of Florida (Homotera:Coccoidea:Coccoidae) Florida depart .Of Agric. 4consumer services vol, 11:194 PP.

Hassan, N.A. (1998). Ecological studies on Insulaspis pallidula on mango trees., J. Agric. Sci. Mansoura Univ., 23 (8): 3986

Helmy, E.I.; El-Imery S.M. and Habib A. (1986). Ecological studies on the Florida wax scale, Ceroplastes floridensis count (Homoptera : Coccidae) on citrus in Egypt. Bull.Soc. Ent., 66: 155-166.

Hosney, M. (1939). On coccids found on roots of plants in Egypt .Technical and Scientific Service. Ministry of Agriculture, Egypt:-24.

Kwaiz, F.A.M. (1999). Ecological and toxicological studies on the mango soft scale, Kilifia acuminata (Signoret) with special reference to insecticide residues in Mango fruits. Ph. D. Thesis Fac. of Agric Cairo Univ., 171 pp.

Laila s.Hamouda (2002).Toxicological and biochemical studies on the effect of Admiral (IGR) and nuclear polyhedrosis virus (SNPV) on Spodoptera littoralis (Bois D.) larva. J. Egypt Acad. Soc. Environ. Develop.( A. Entomology ), 2(1):15-29. 
Miller, D.R.;Williams, D. J. and Davidson, J. A. (2006). Key to conifer-infesting species of Lepidosaphes Shimer world wide (Hemiptera: Coccoidea: Diaspididae), with descriptions of two new species and a redescription of L.palliddula (Williams). Zootaxa www.mapress.com.

Moffit, L. J. (1999). Economic risk to united states agriculture of Pink hibiscus, European and Mediterranean Plant Protection Organization, 2005. http.//www. eppo.org/ Quarantine/ insects/Ds_Maconellicoccus_hirsutus.

Nada, S.; Abd-Rabau, S. and Hussein G.E. (1990). scale insects infesting mango trees in Egypt in Egypt (Homoptera: Coccoidea). Proc. Issis. Vi, Krakow part 11:133-134.

Radwan S.A (2003). Toxicological studies on some scale insects infested mango and guava trees.Ph.D.Faculty of Agriculture Cairo University.

Sharaf, M. R. (2005):Taxonomic and ecologic studies on family Formicidae (Order: Hymenoptera) in Egypt including some protectorates with a study of some insect fauna associated with ant species. PhD. Ain Sams University.

Watson, G.W. (2009). Arthropods of Economic importance. Diaspididae of the world. E TI CD ROM. Notural hiotory Museum, London. http.//nlb.f.eli.uva.nl/bis/diaspididae of the world S.A.ulen berg (series editor).

Wales, J. (2009).Founder of Wikipedia. The free encyclopedia, Wikimedia Foundation, Inc.MediaWiki en.wikipedia.org/wiki/Mealy bugs. 


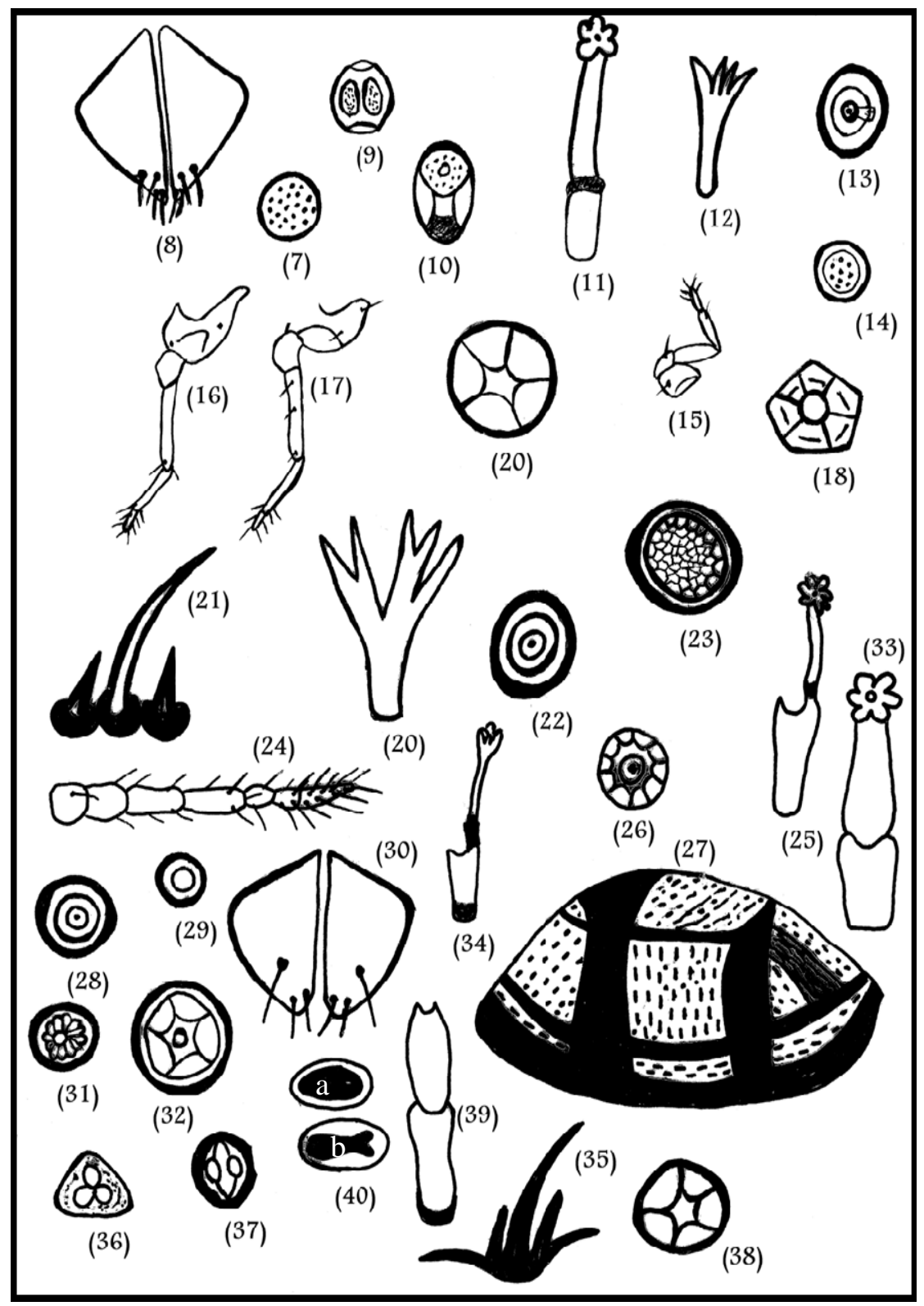

EXPLANATION OF FIGURES

Figs. (7-12) Pulvinaria psidii Maskell, 7: discoidal pores, 8: anal plates, 9:bitubular pores, 10: sclerotized spiracular plate, 11: tubular ducts, 12: marginal setae. Figs. (13-21) Kilifia acuminate (Signoret), 13: submarginal tubercles, 14: disc pores, 15: foreleg, 16: midleg, 17: hindleg, 18: quinquelocular pores, 19: anal quinquelocular pores, 20: marginal setae, 21: spiracular setae. Figs. (22-26) Coccus hespridum L., 22: submarginal tubercles, 23: preopercular pores, 24: antenna, 25: tubular ducts, 26: multilocular pores. Figs. (27-32) Saissetia oleae (Oliver), 27: adult female, 28: submarginal tubercles, 29: discoidal pores, 30: anal plates, 31: multilocular pores, 32: quelocular pores. Figs. (33-35)Saissetia coffeae(Walker), 33: ventral tubular ducts, 34: tubular ducts with thin filaments, 35: spiracular setae. Figs. (36-39)Ceroplastes floridensis Comstock, 36: trilocular, 37: bilocular, 38: quinquelocular pores, 39: tubular ducts. Figs. 40: (a \& b) Coccus hespridum L 

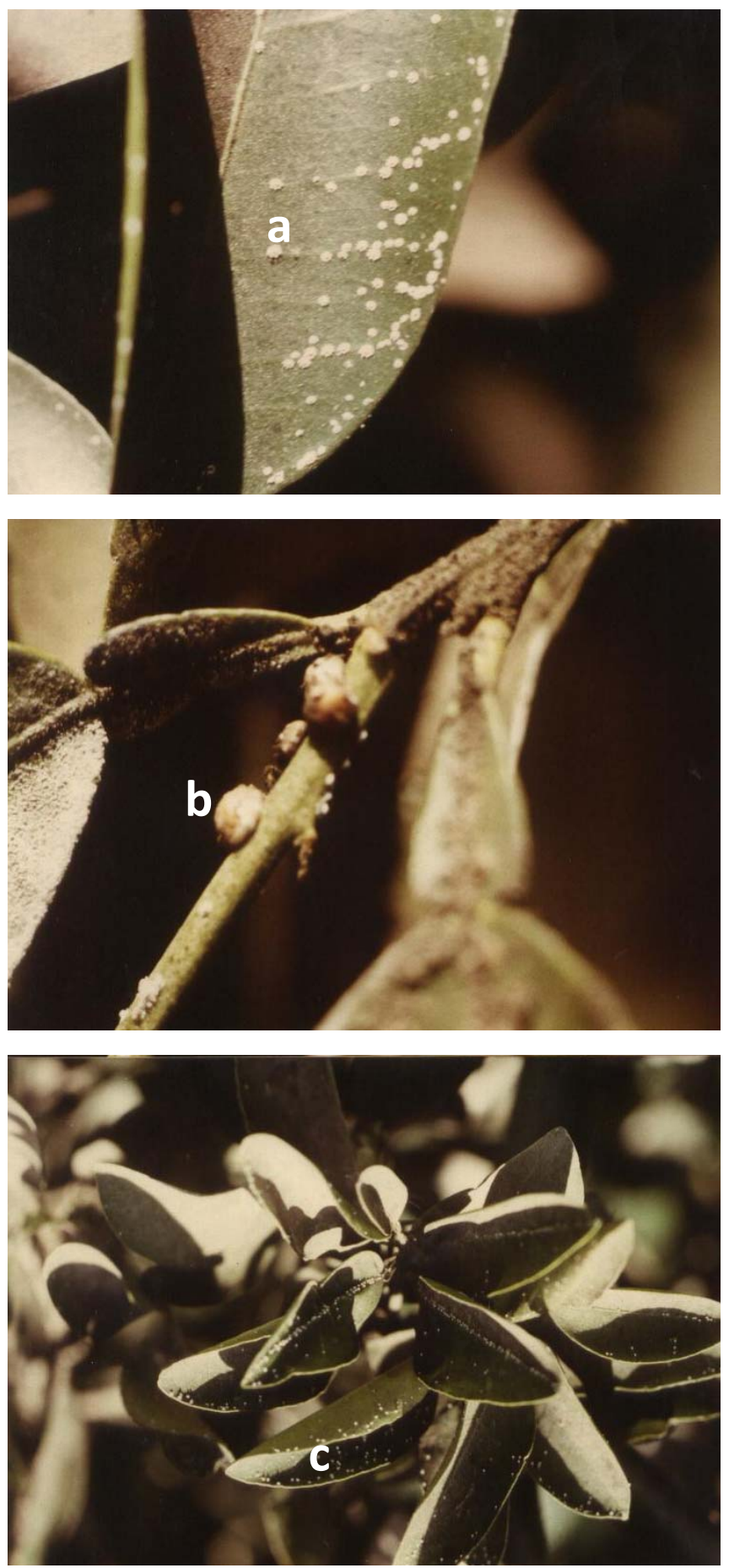

Fig. 41: Ceroplastes floridenses (a) preadults on lower surfaces,

(b) adults on branches (c) on upper surfaces and on midribes. 

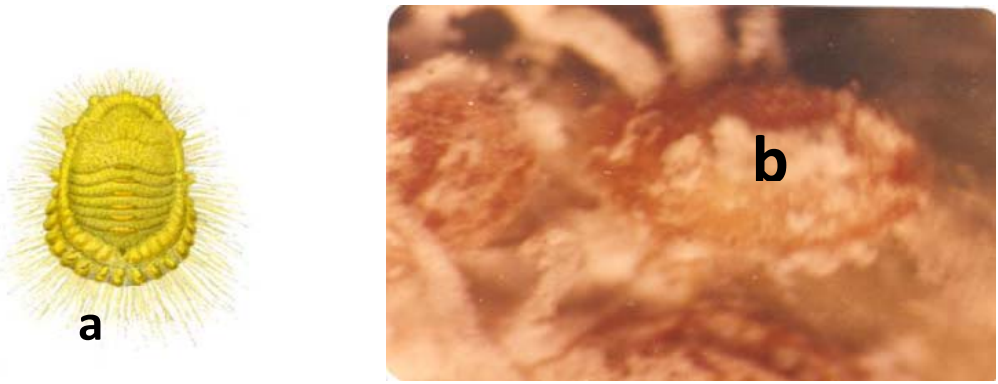

Fig. 42: Icerya seychellarum (a) female, (b)the spherical cyst

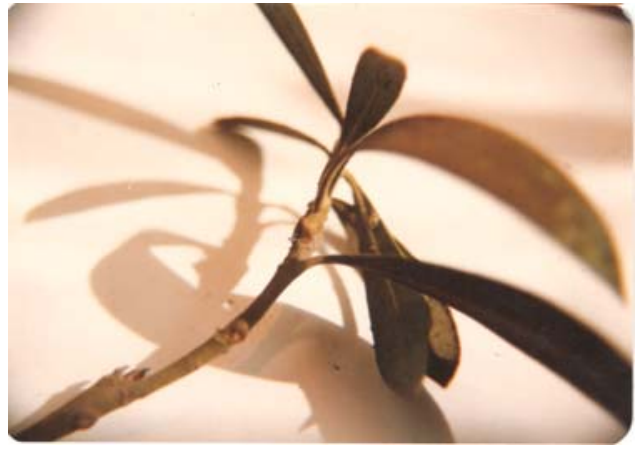

Fig. 43: Saissetia coffeae (Walker)
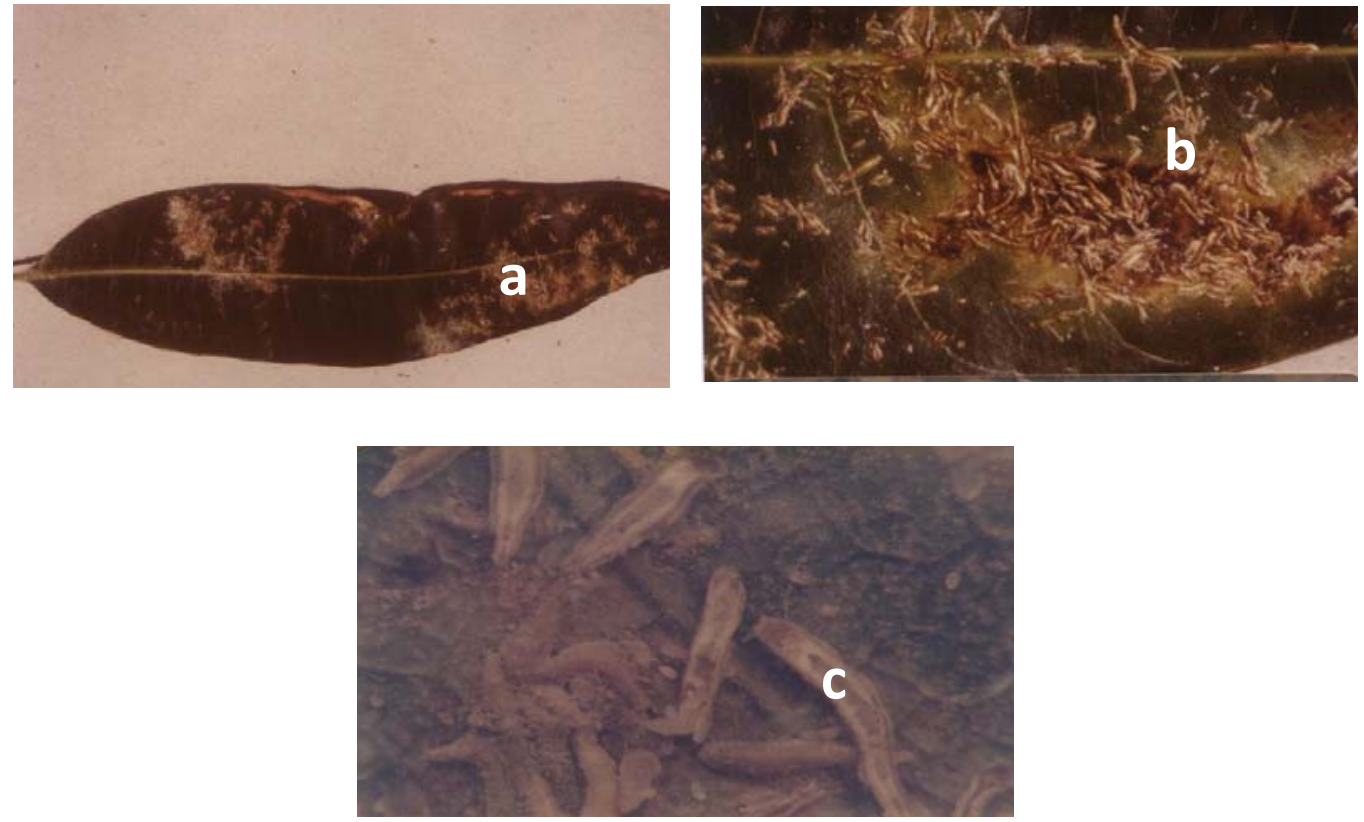

Fig. 44: Lepidosaphes pallidula (a ,b) clusters on mango leave (c) inverted individuals. 


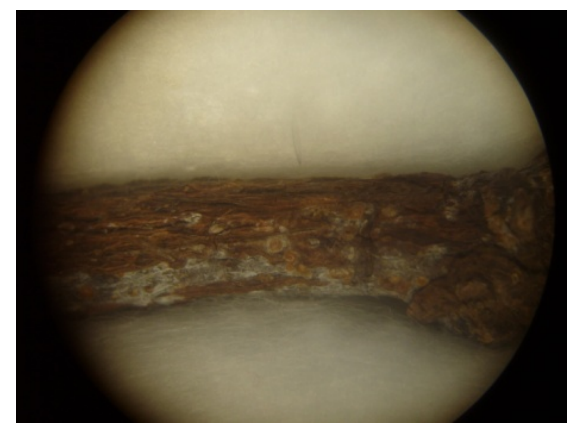

Fig. 45: Aonidiella aurantii (Maskell)

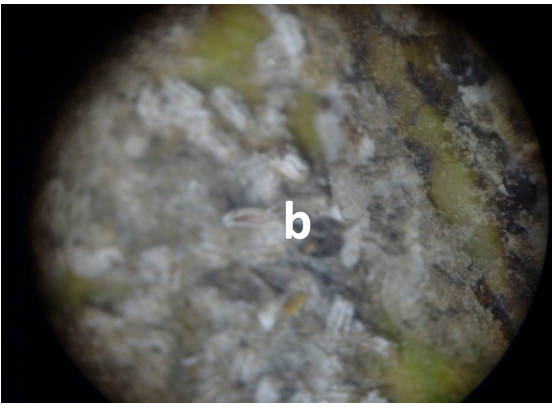

Aulacaspis tubercularis (b) male

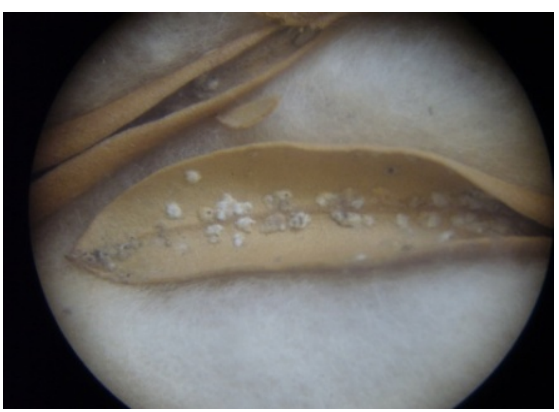

Fig. 47: Aspidiotus nerii Bouche

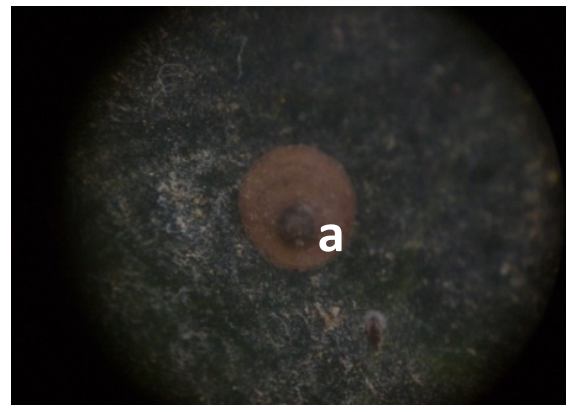

Fig. 49: Lindengasis floridana (a) adult scale

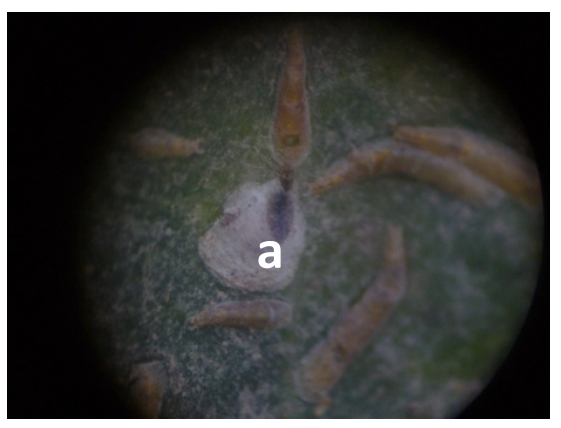

Fig. 46: Aulacaspis tubercularis (a) female

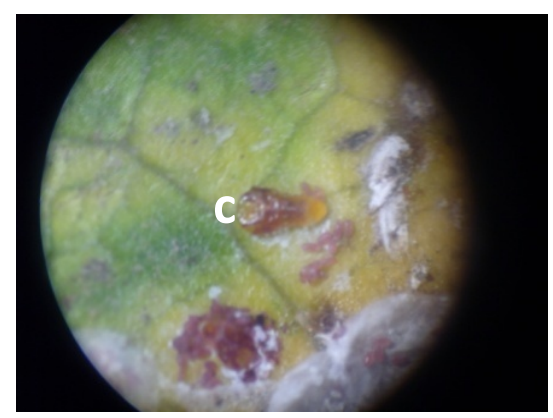

Aulacaspis tubercularis (c) female without scale

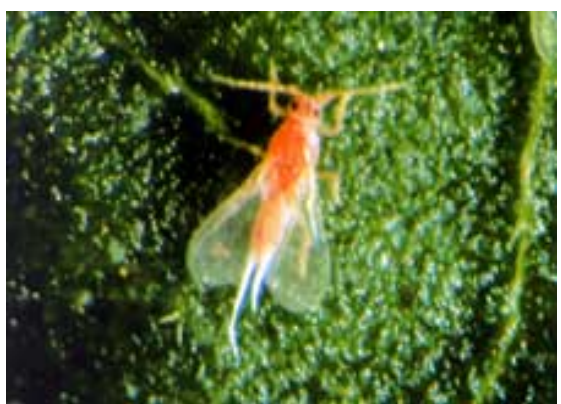

Fig. 48: Maconellicocus hirsutus male

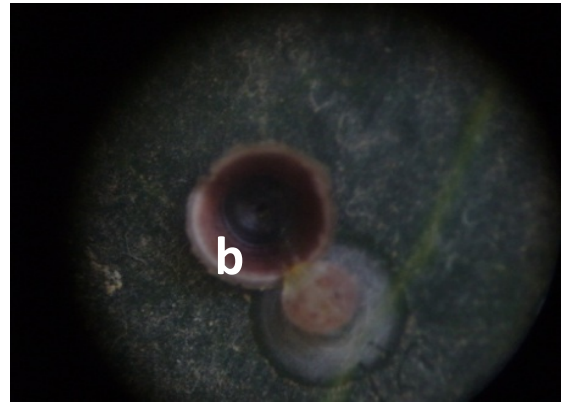

Lindengasis floridana ( b) with inverted cover scale 

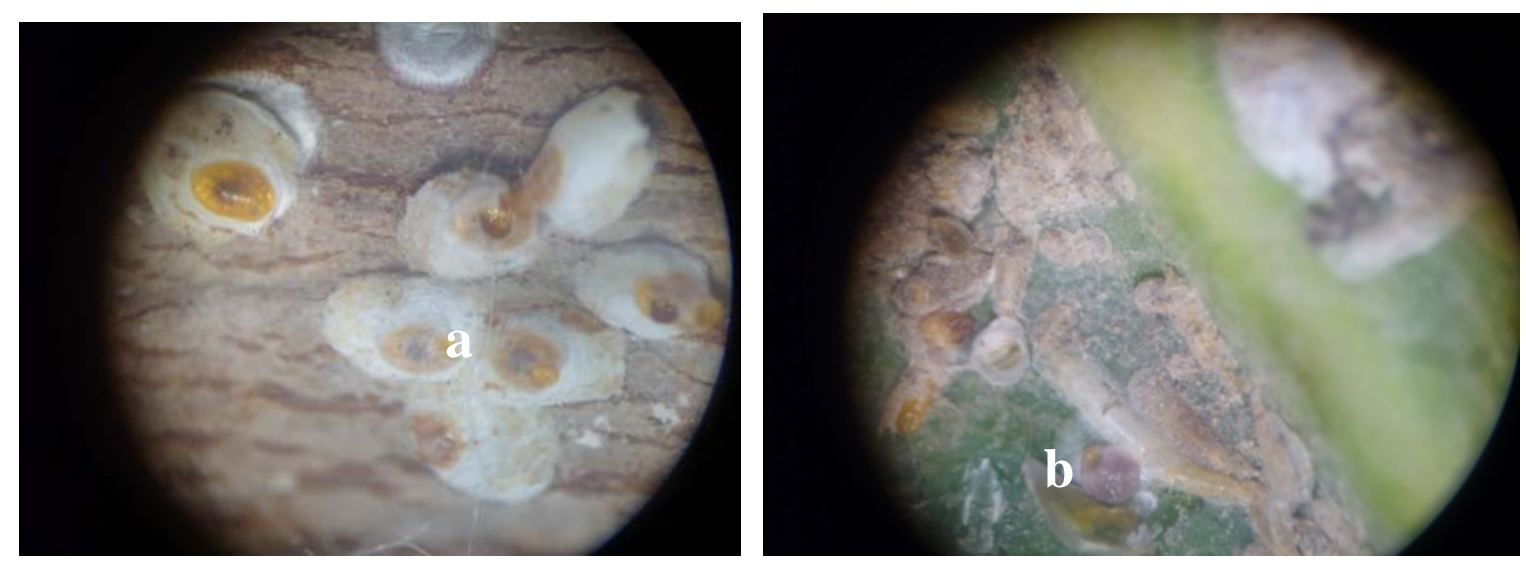

Fig. 50: Parlatoria oleae (Clovee) (a) adult olive scale Parlatoria oleae (Clovee) (b) exposed violet female without scale.

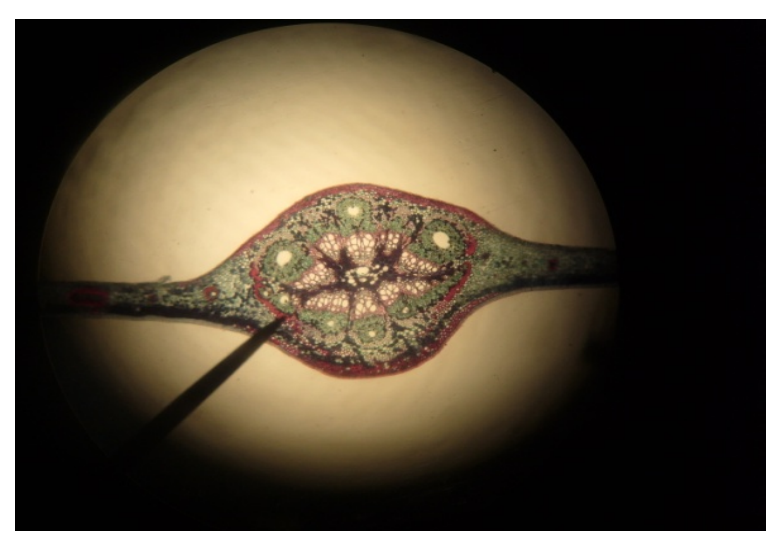

Fig. 51: T.S. of Alphonso mango leaf

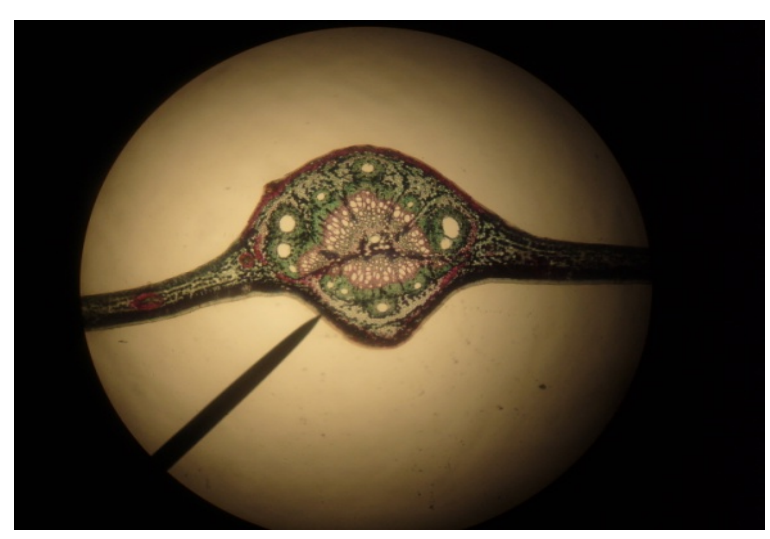

Fig. 52: T.S. of Hendi mango leaf 


\section{ARABIC SUMMARY}

\section{دراسات بيئية وتصنيفية على الحشرات القشرية التى تصيب أثجار المانجو لثثلاثة أصناف مختلفة فى محافظة القليوبية}

رضا فضيل على بكر1 ، روضة محمد عبد الحميد بدوى 1، صابر فهيم موسى² ، ليلى سبد حموده1

\section{سحر على عطية}

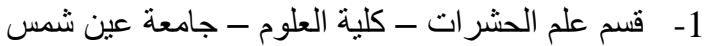

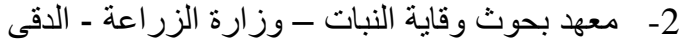

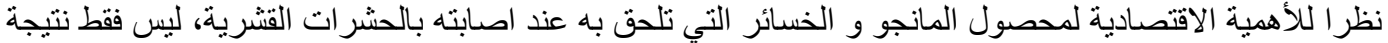

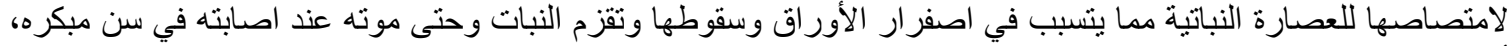

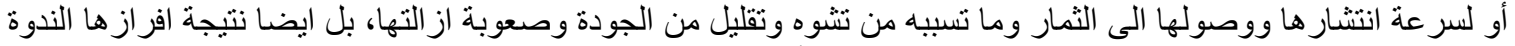

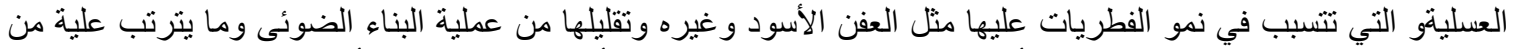

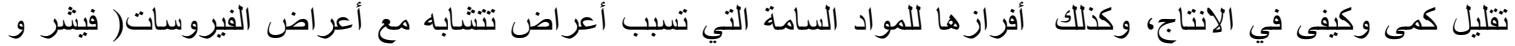

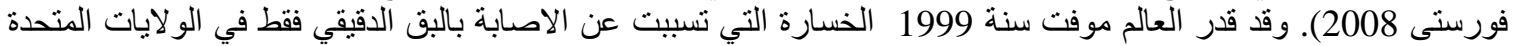

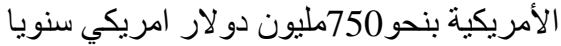

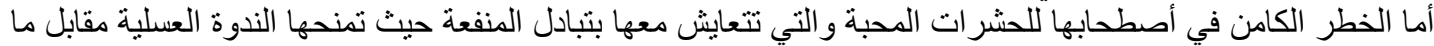
توفره لها من حماية من الأعداء ولوحظ كبر المستعمر ات التي تصطحب النمل والدبابير وتتعايش معها حتى تحت غطاء ولثاء واحد

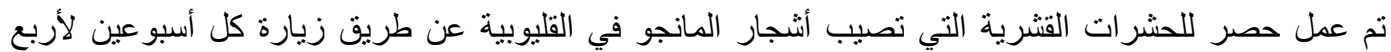
مشترك.

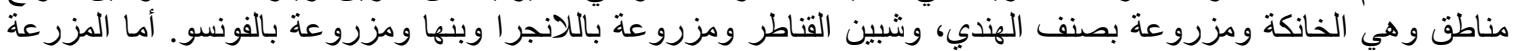

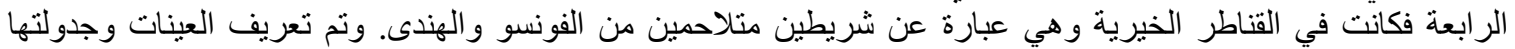

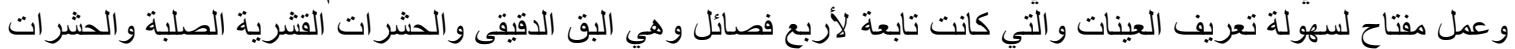

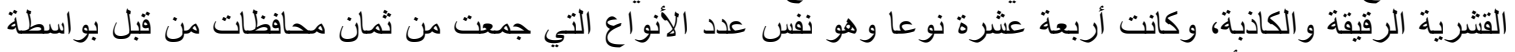

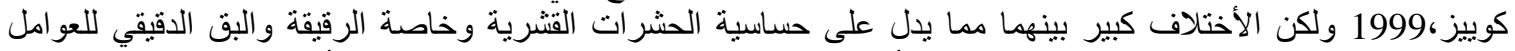

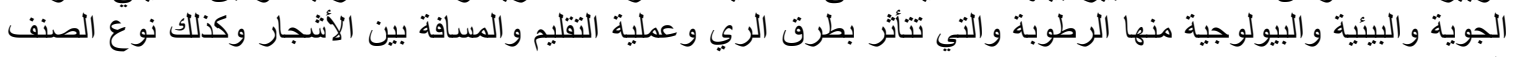

ونظر الوجود تنوع كبير في الثكل الظاهري حسب المنشأ و العمر و العائل لذلك احتاج تعريف العينات الى تعريف المزروع.

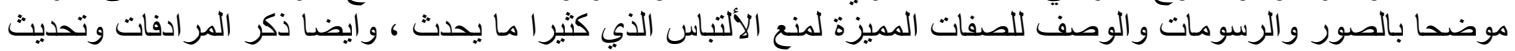
الأسماء تبعا للوضع التور والرسنيفي الحديث.

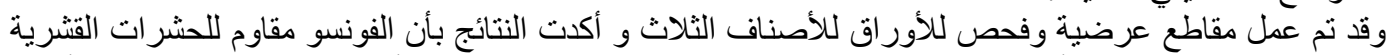

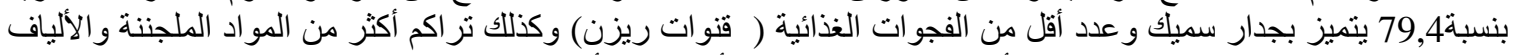

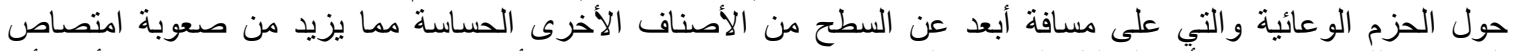

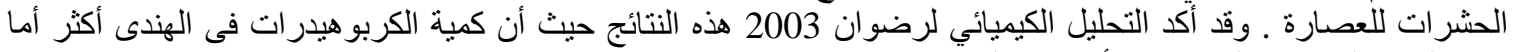

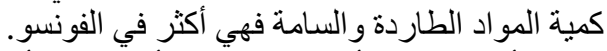

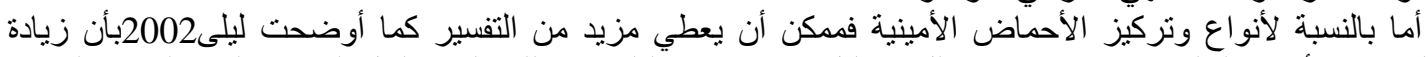

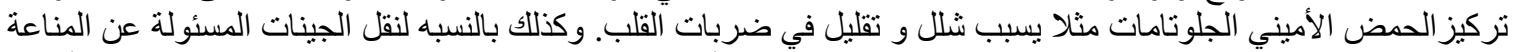

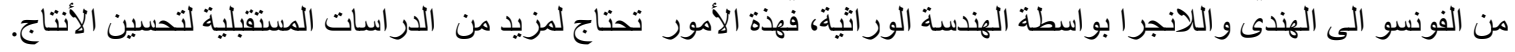

